\title{
INVISIBLE INFORMALITY AND THE CONTRIBUTION OF INFORMATION MODELING TO DATA-BASED URBAN REGULATION
}

INFORMALIDADE INVISÍVEL E A CONTRIBUIÇÃO DA MODELAGEM DA INFORMAÇA PARA UMA REGULAÇÃO URBANA BASEADA EM DADOS

\author{
Mariana Quezado Costa Lima ${ }^{1}$, Clarissa Figueiredo Sampaio Freitas ${ }^{1}$, Daniel Ribeiro \\ Cardoso $^{1}$
}

\section{ABSTRACT:}

Recent studies have established the role of urban planning policies in feeding the growth of informal settlements in Brazilian cities, through the socio-spatial exclusion of low-income residents. The difficulties of reversing this exclusionary logic are due to several complex factors. The invisibility of the informal city is a factor less discussed in Brazilian literature, but it has begun to draw the attention of scholars. This work aims to show how the invisibility of the informal city is a structural component to explain the inadequacies of urban regulation in addressing the urban needs of precarious informal settlements. After discussing the phenomenon of urban informality in Fortaleza, we applied a methodology that combines Geographic Information Systems (GIS) and City Information Modeling (CIM), to support the redefinition of urban rules for precarious informal settlements. This procedure will reveal not only the extent of the inadequacies of the (past and current) land use and occupation codes but will also present some potentialities of GIS and CIM to inform its redefinition.

KEYWORDS: informal settlements; Geographic Information System; City Information Modeling; urban form

\section{RESUMO:}

Estudos recentes têm estabelecido o papel das políticas de planejamento urbano na alimentação do crescimento dos assentamentos informais nas cidades brasileiras, por meio da exclusão socioespacial de moradores de baixa renda. As dificuldades de reverter essa lógica excludente se devem a vários fatores complexos. Um fator menos discutido, principalmente na literatura brasileira, mas que começa a chamar a atenção dos estudiosos, é a invisibilidade da cidade informal. Esse trabalho visa mostrar como a invisibilidade da cidade informal é um componente estrutural para explicar as inadequações da regulação urbana em atender às necessidades urbanas de assentamentos informais precários. Após discutir o fenômeno da informalidade urbana em Fortaleza, aplicamos uma metodologia que combina Sistemas de Informação Geográfica (SIG) e Modelagem de Informação da Cidade (CIM), para subsidiar a redefinição das regras urbanas para assentamentos precários de origem informal. Este procedimento revelará não apenas a extensão das inadequações (históricas e atuais) das leis de uso e ocupação do solo, mas também apresentará algumas potencialidades do SIG e do CIM para informar sua redefinição.

PALAVRAS-CHAVE: assentamentos informais; Sistema de Informação Geográfica; Modelagem da Informação da Cidade; forma urbana.
Fonte de Financiamento: CNPq / CAPES

Conflito de Interesse: Declara não haver.

Ética em Pesquisa: Declara não haver necessidade.

Submetido em: 04/04/2021 Aceito em: 28/08/2021 


\section{INTRODUÇÃO}

Recent studies have established the role of urban planning policies in feeding the growth of informal settlements in Brazilian cities, through the socio-spatial exclusion of low-income residents (e.g. ROLNIK, 2015). Although aware that informality is a consequence of a structural and complex process within the capitalist system, as analyzed by Rolnik (2015), we align with the view that housing informality is a by-product of restrictive urban regulations, which historically defined an ideal city model that ignores the needs and payment capacities of most of the population (CYMBALISTA, 1999; MARTINS, 2006).

When referring to the phenomenon of informality, we will adopt the definition of Castells and Portes $(1989$, p. 12), who presents informality as an activity that "[...] is unregulated by the institutions of society, in a legal and social environment in which similar activities are regulated". According to this definition, informality is, therefore, intrinsically related to State action, particularly through regulation. With this statement, while presenting the risk of naturalizing a precipitated dichotomy between formality and informality, the authors reveal that what is considered informal in each place depends on the standards established in that society about what is considered formal. In this sense, any definition of informality must precisely specify the regulatory framework in question (KANBUR, 2009) and must treat it as a process and part of a historical, political and social context.

We understand urban regulations as the set of parceling norms, land use regulations and building standards, which are often applied in the form of zoning codes that are part of Brazilian urban master plans. These codes affect the social distribution of urbanized territory, by defining the conditions and parameters that establish the threshold of what is considered a formal/legal urban settlement (MARTINS, 2006; MAGALHÃES, 2013). Beyond this threshold, there are territories where the State's social protection is not guaranteed, especially with regards to access to urban services. Moreover, although most cities have some level of disagreement with the urban law, some types of informality are authorized by the State and often practiced by it - considered as "flexibility" - while others are criminalized according to unfair criteria and suffer from its consequences (FREITAS, 2014; ROY, 2009). This selective law enforcement is due more to the socioeconomic and/or racial characteristics (MUKHIJA; LOUKAITOU-SIDERIS, 2015) of the people who practice the activity than to the characteristics of the informal activity itself. This can be considered a constant in different geographic realities, given the reports of authors about the United States (EHRENFEUCHT; LOUKAITOU-SIDERIS, 2014), Brazil (MARICATO, 2013), South Asia and the Middle East (ROY; ALSAYYAD, 2004).

In Brazil, over the years after the re-democratization, since the Federal Constitution of 1988, several advances have occurred concerning the legitimacy of precarious informal settlements, which have enabled their provision of services and infrastructure through development projects. These constitute important steps towards the recognition of residents' rights. Despite this progress in the legal dimension, little has been made concerning standards to ensure quality of the built environment. The difficulties of reversing the urban planning exclusionary logic are due to several complex political, economic and cultural factors. A factor less discussed, especially in the national literature, but that has begun to draw the attention of scholars, is the invisibility of the informal city (FREITAS; GOMES; BORGES, 2013; LUQUE-AYALA; MAIA, 2018).

This research is, therefore, in line with the statement that invisibility is a structural component in understanding the limits of urban planning policies in major metropolises of the Global South, as suggested by Roy (2009), which uses the term "unmapping" to define this selective and symbolic misinformation about the informal city. The solutions are usually pointed out without a spatial understanding of the problem and access to information on informal areas is not placed as an obstacle. In this sense, this study focuses on spatial issues and techniques for 
collecting and systematizing data about the informal city, an approach little discussed in the literature, which usually directs its efforts towards political and legal challenges (e.g. FERNANDES, 2011).

Although the search for spatially represented information is not a contemporary exclusivity, considering the use of maps since antiquity, city representation was improved through the various technological advances in recent years. Historically, maps were designed by dominant groups and for dominant groups, showing and hiding aspects of reality according to the involved interests. The forms of use of these cartographies have been modified over time and accompanied the technological development of other areas of science, notably by military and environmental needs (PEREIRA; SILVA, 2009). This development is viewed with suspicion by some authors who see technology as a reinforcing concentration of media power. Indeed, digital visibility initiatives presented as empowerers and promoters of urban inclusion are usually part of a much more complex network of power, as pointed out by Luque-Ayala and Maia (2018). On the other hand, new information technologies seem to positively impact the contents, forms and means of control over cartographic representation. These technologies have the potential expand the focus of planning a design initiative toward precarious informal settlements.

We acknowledge some important advances in the visibility of informal settlements in Brazil, made in the 2000's, with emphasis on the operationalization of the concept, the definition of its limits and the quantification of its inhabitants (IBGE, 2010). Taking this into account, our research highlights that it is not sufficient to know how many people live in such settlements and their boundaries, it is necessary to compile data about their urban form and their built environment. This research assumes that it is necessary to regulate (establish rules for) the urban form of precarious informal settlements, in order to prevent the deterioration of their urban environmental quality. Although irregularity is not restricted to precarious settlements, it is in them that the lack of compliance with urban norms takes its most perverse form.

In order to unite these dimensions - the invisibility of the informal city, the impact of this invisibility for exclusionary regulations (and vice versa) and the potential of new information technologies to overcome the technical obstacles - we inquiry: how can City Information Modeling (CIM) contribute to a reality-based regulatory policy for precarious informal settlements?

The work aims to show how the invisibility of the informal city is a structural component to explain the inadequacies of urban planning in addressing the urban needs of precarious informal settlements. With this major purpose, we employ a case-study-based approach, using Geographic Information Systems (GIS) and urban modeling resources in Fortaleza (Brazil), to identify these inadequacies to develop reality-based regulations. In order to regulate informal settlements in a way that qualifies their urban environment while respecting their specificities, there are technical and political-economic limitations, which have dialectical relationship. Although addressing both dimensions and their close relationship, the work focuses on methods to overcome/attenuate technical obstacles. This is one of the main contributions of this work.

In the first part of the article, we analyze the historical process of regulating Fortaleza's urban expansion, paying particular attention to the meaning of informality in the subsequent urban plans until nowadays. We also apply calculation tools of a GIS software (Qgis) on some official data, to estimate the phenomenon of urban informality as it is currently manifested in Fortaleza. In the following part, we describe the methods used to recognize the problems of current urban regulation, as well as to produce/represent information about informal settlements. The first applied method uses GIS software to overlap official data on the planned versus the actually implemented urban environment in some areas of the city. Then, in these 
same areas, we used urban modeling software (City Engine) to simulate how an existing block would be like if in accordance with current legislation and compared this simulation with the encountered reality. A third method is proposed in a case-study area in Fortaleza periphery, this time combining Qgis with an algorithmic modeler (Grasshopper), to point out a possible path to acknowledge informal settlements built environment. Finally, through the results of the applied methods, we analyze the contributions of GIS and CIM to a reality-based regulatory policy for informal settlements.

\section{THE LEGAL CITY: INFORMALITY (NOT) SEEN BY URBAN PLANS}

Fortaleza is the capital of the state of Ceará, located in northeastern of Brazil (Figure 1), and it is the largest city in a metropolitan region with 18 municipalities. In less than six decades, Fortaleza quintupled its population, from 514,000 inhabitants in 1960 to about 2.6 million in 2015 (IBGE, 2016). It is nowadays the fifth largest city of the country and also the fifth most unequal city in the world (UN-HABITAT, 2010). Violence and precariousness are spatially concentrated on the precarious low-income informal settlements, which according to official numbers house more than $40 \%$ of current city population (FORTALEZA, 2012).

Figure 1. Location of Fortaleza.

Source: produced by the authors, based on data from IPECE, 2016

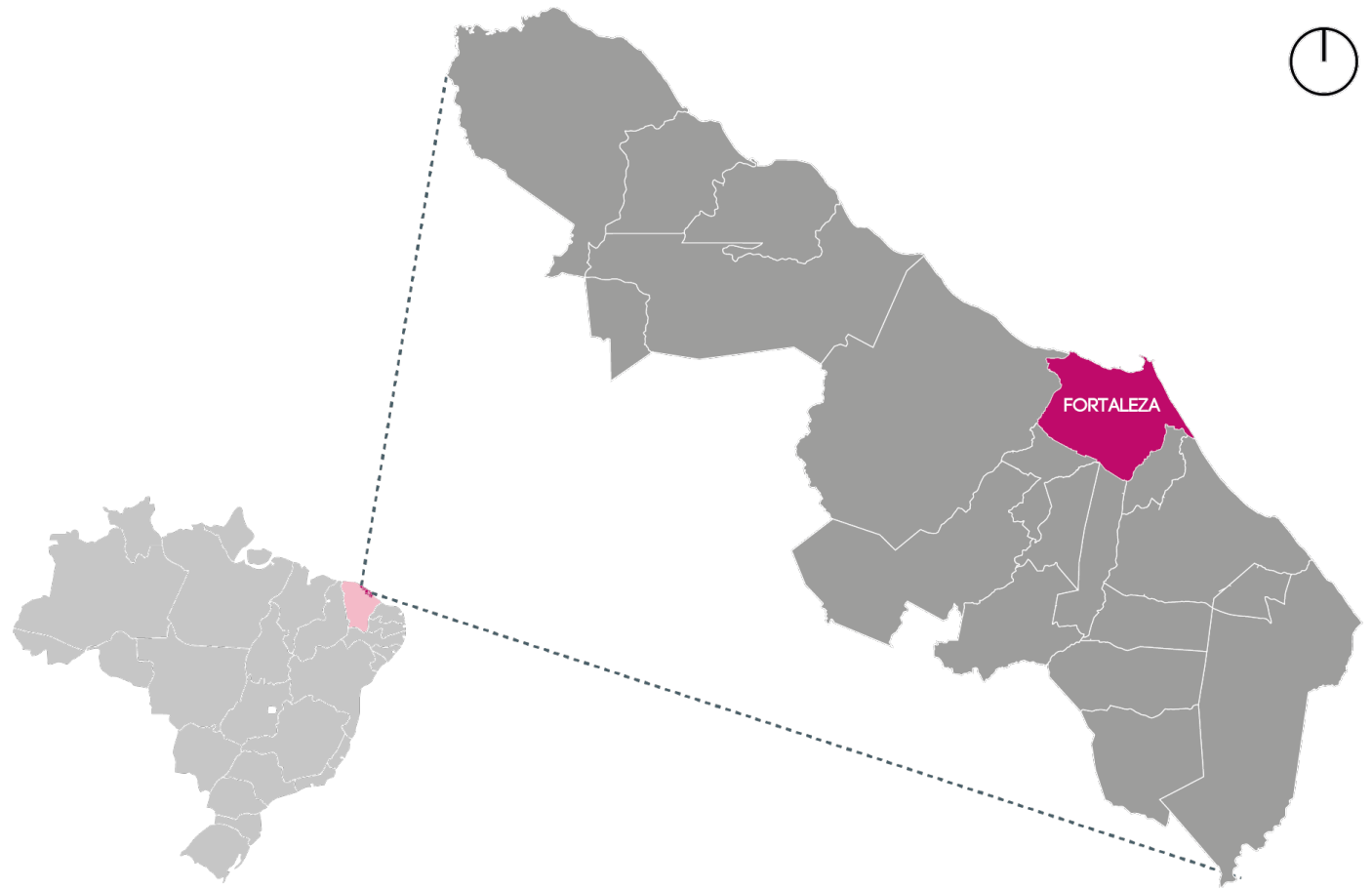

With no claim to make a complete historical survey of Fortaleza's urban plans, we picked some examples of planning documents within the twentieth century to analyze how housing informality was described by them. The twentieth century seems to be a good time frame, as it corresponds to the period when the urbanization process in Fortaleza took place. The documents analyzed were mostly of two types: posture codes ("Códigos de Obras e Posturas", in Portuguese) and master plans ("Planos Diretores", in Portuguese). The formers, as the name suggests, regulate the behaviors of the citizens, but also discipline the traffic, streets and lots alignments, and buildings' construction and maintenance. We analyzed the following posture codes: Decree n. 70, 1932; Law n. 188, 1950; Law n. 2004, 1962; Law n. 5530, 1981; and the 
following master plans: Law n. 2128, 1963; Law n. 5122, 1979; Law No. 7061, 1992; Law No. 062, 2009.

A quick analysis of the historical planning documents reveals that urban informality is rarely mentioned by the plans that guided the urban development of Fortaleza: among the eight documents analyzed, only three mentioned the phenomenon. During the second half of the twentieth century, although socio-spatial contradictions and inequalities were spreading across the city, plans continued to deal with idealized models, assuming conflict-free territory. They either pretended that the informal city did not exist or, when recognized its existence, reinforced stigmatized conceptions. The 1963 Master Plan, for example, places the blame for the "problem of the slums" on the residents themselves and refers to them as "outcasts", which, by definition, means those who do not fulfill their social role or those who do not have the same rights as others (FORTALEZA, 1963, p. 34).

Other official planning documents set minimum land use standards that were far above the economic reality of recent migrants from the impoverished countryside. These standards, probably imported from European urban regulations, as well as in other Brazilian cities (ROLNIK, 1997), demanded single-family detached houses in large lots, separated from the street and from the neighbors. Indeed, these codes prohibited cohabitation and required a large minimum lot size (Figure 2). Even when the plans stimulated the construction of affordable houses, posture codes limited this construction to areas outside the urban perimeter and, therefore, outside the scope of regulation. Therefore, these plans assumed an order that contemplates only a small part of the city.

The more the reality of informality was ignored by the plans, the more it grew and reiterated its exploitative character on the informal dwellers. More recently, we witnessed the great progress that was the recognition of the legitimacy of precarious informal settlements, although their existence has been accepted as exception and object of intervention. Nevertheless, the fact that most of the city have characteristics that were not allowed by the previous plan have been systematically ignored in each ensuing plan and continue to be in the current planning system. The regulation remains disconnected to the existing urbanization dynamics, which persist not capable of informing new procedures. Official plans continue not to put the phenomenon of informality as one of the major challenges of urban policies and even the most basic planning steps such as measuring, understanding its causes and building data are seldom undertaken.

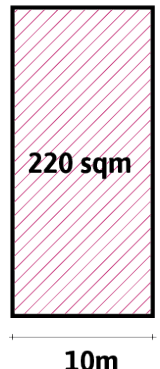

$10 \mathrm{~m}$

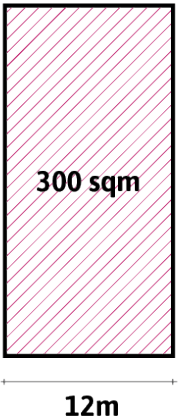

1950 and 1962

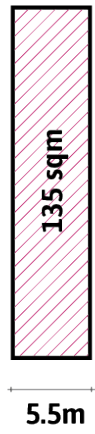

1979

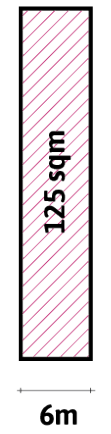

1992 and 2009

This brief analysis of the discourses and regulations of Fortaleza's master plans does suggest some evolution in the way official planning understand housing informality. Comparing the earlier "victim-blaming" point of view to more recent strategies of toleration and acceptance we can perceive a greater legitimacy of informal settlements. Yet, information and knowledge 
about these settlements, their features, their limitations and their intrinsic qualities have always been lacking.

In the 2000s, each Brazilian municipality was required to revise its Master Plan according to the Federal Bill guidelines, and to develop a Social Housing Plan (Plano de Habitação de Interesse Social (PLHIS), in Portuguese), as a requirement to access the National Housing fund created in 2005. Even though Fortaleza's Social Housing Plan (developed between 2010 and 2012) was never implemented, it constitutes an important source of information about its precarious informal settlements. The information produced highlighted the dimension of the problem to decision makers. According to the estimates of the survey conducted in 2010, within the context of the Social Housing Plan, there are 1,077,059 dwellers living in 843 precarious settlements, accounting for $44 \%$ of the city population. This significant part of the population is concentrated in about $12 \%$ of the territory.

These settlements tend to accumulate several layers of informality. First of all, their land tenure status do not comply with formal processes of land registry. While some of them are result of occupation of private land, a great number of them comprise subdivisions that were never registered in notary's office. Thus, while the original owner has sold pieces of his land to some families and opened unregistered streets planning agencies have no formal knowledge of that. In other cases, public land was occupied, not rarely with the tacit allowance of elected officials, who have warranted protection against eviction. This is thus the first dimension (layer) of informality: it refers to property, to land titles.

The second dimension (layer) of informality present in these settlements refers to urban codes and parameters. As there was no formal selling, or transfer of property, all the other steps that regulate urban development of the formal "planned" city were not taken. This explains their insufficient area of public spaces, absence of setbacks which make it impossible to open widows, narrow streets, that turn into alleys as buildings advances over spaces reserved for circulation, and self-built verticalization to fit the expansion of families or for sale / rent.

Yet, while public opinion, and even many of local planners, equate informal settlement with precarious settlements, we should note that informal urban land occupation is not limited to precarious housing. A much larger portion of the city is not in accordance with the parceling norms, land use regulation and/or building standards. Moreover, the noncompliance with these rules is not restricted to poor households, since it is not uncommon to find high-end buildings that do not meet the regulation, especially those relating to the maximum height and/or land use intensity. On the other hand, when informal land occupation occurs because of economic survival, in general, it does not meet standards like lot size, setbacks and/or coverage. However, it is worth mentioning that, although urban informality is not restricted to precarious settlements, it is in them that noncompliance with urban norms takes its most perverse form. To get an idea of how much of the city is outside the scope of the regulation but keeping in mind that the phenomenon is even greater - we gathered on the same map (Figure 3) the precarious settlements and the lots whose areas are smaller than allowed by the current parceling regulation (that is less than 125 square meters). 


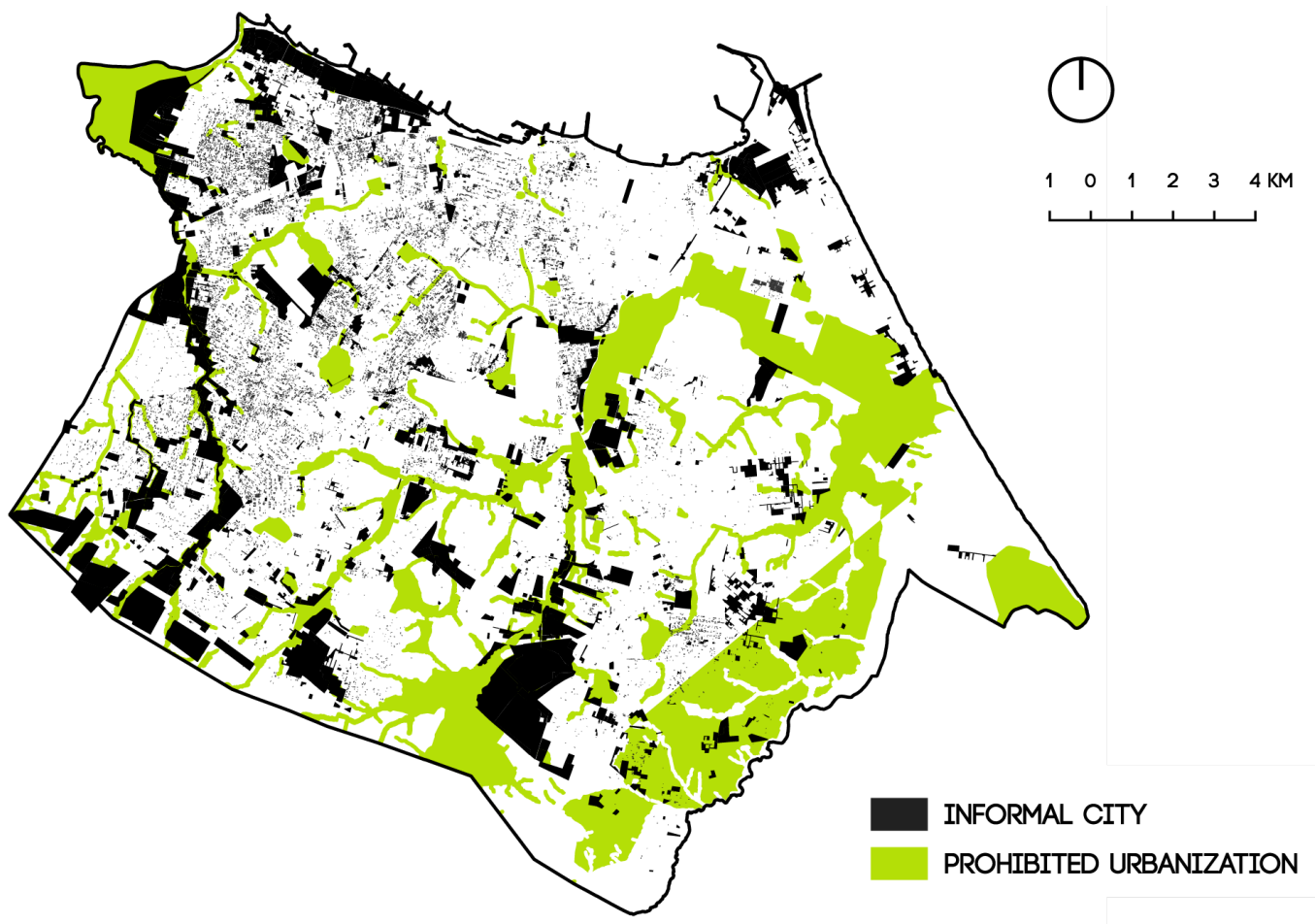

The extensive misrule of urban laws is not a particularity of Fortaleza: it reaches over $50 \%$ of the buildings in major Brazilian cities, if we consider the land use and building regulations, zoning and land parceling norms (MARICATO, 1996). This result confirms some proposals that question the legitimacy of the urban regulations, as their standards and their application produce informality (e.g. MARTINS, 2006, p. 42):

Here becomes apparent the large gap between the desirable (standards established in law) and the urban reality. In most of our metropolitan cities especially in its peripheral portion - irregularity prevails in quantity and extension in comparison with the regularity. In these conditions, what might be called regular or 'standard'?

\section{VISUALIZATION APPROACHES VIA INFORMATION MODELING}

To illustrate the potential of geotechnologies to contribute to overcoming the obstacles reported above, we used urban modeling as a resource to increase the visibility of some aspects of the phenomenon, gradually increasing the complexity of the system.

In the first exercise, we overlayed official shapefiles in QGIS, a GIS application. In the second, with the same areas used in the first exercise, we adopted Esri City Engine to simulate urban parameters. Finally, a more robust method was implemented, using City Information Modeling - CIM (DUARTE et al, 2012) to measure urban form via density indicators (BERGHAUSER PONT; HAUPT, 2010) in a set of precarious settlements.
Figure 3. Informal City in Fortaleza.

Source: produced by the authors, based on data from SEFIN, 2010 and PLHIS (Fortaleza, 2012). 


\section{LEGAL CITY VERSUS EXISTING CITY}

Through QGIS, official data from subdivision projects were overlayed with the official data of the existing lots. We chose three examples of land subdivision in different areas of the city, approved in different decades of the twentieth century, to compare the design of approved lots with the design of the settlement effectively implemented. As we can see on the images below, the actual limits of the lots differ from the approved subdivision, usually by generating smaller lots (Figures 4, 5 and 6).

Figure 4. "Parque Vila Velha" Subdivision (1976).

Source: produced by the authors, based on data from SEUMA, 2015 and SEFIN,

2010.

Figure 5. "Vila Paraíso" Subdivision (1976).

Source: produced by the authors, based on data from SEUMA, 2015 and SEFIN,

2010.
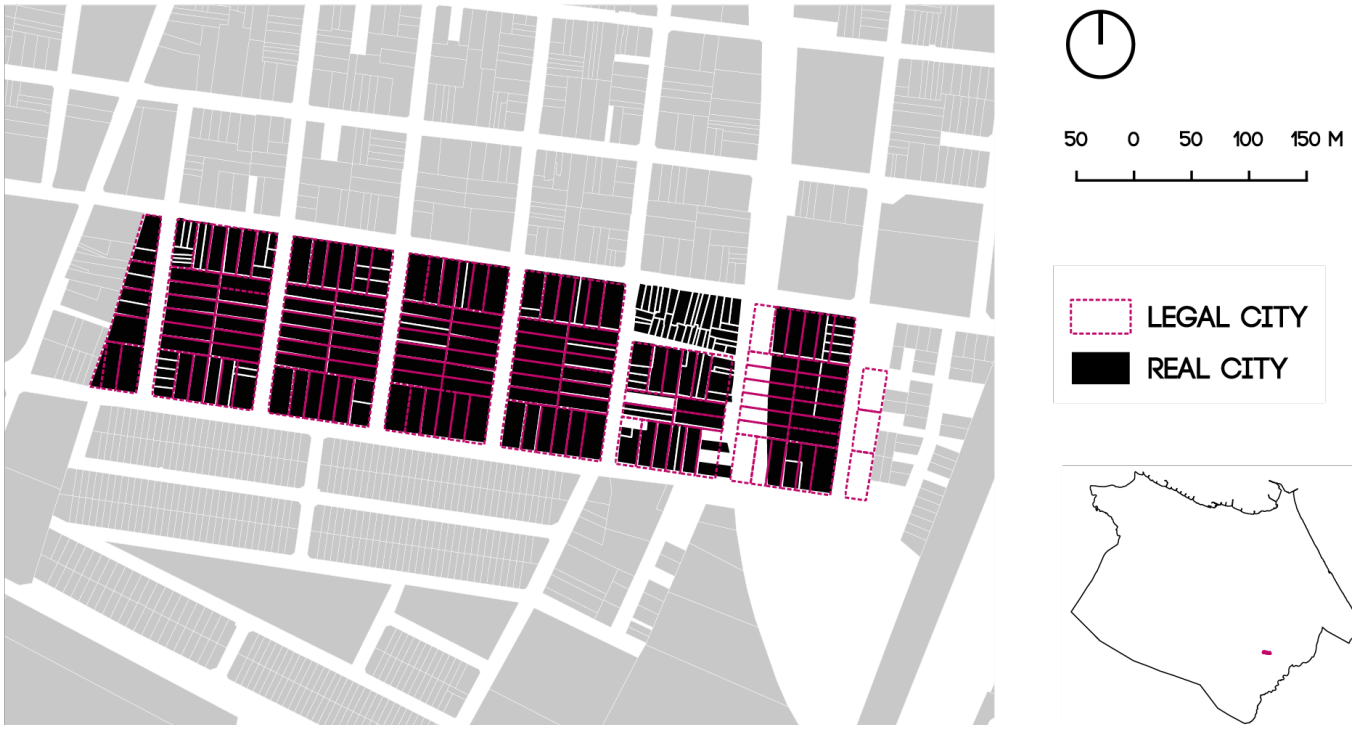

REAL CITY
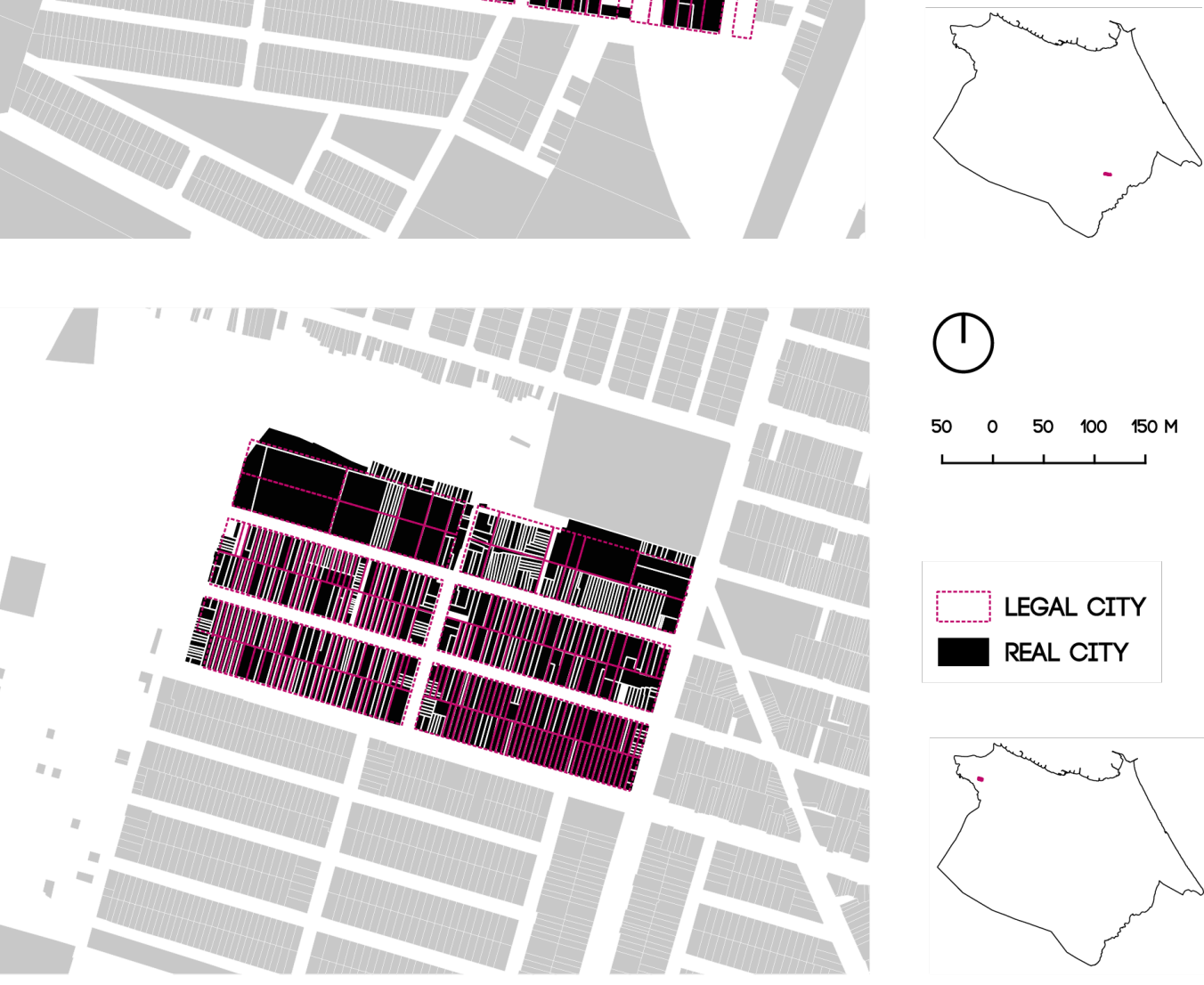

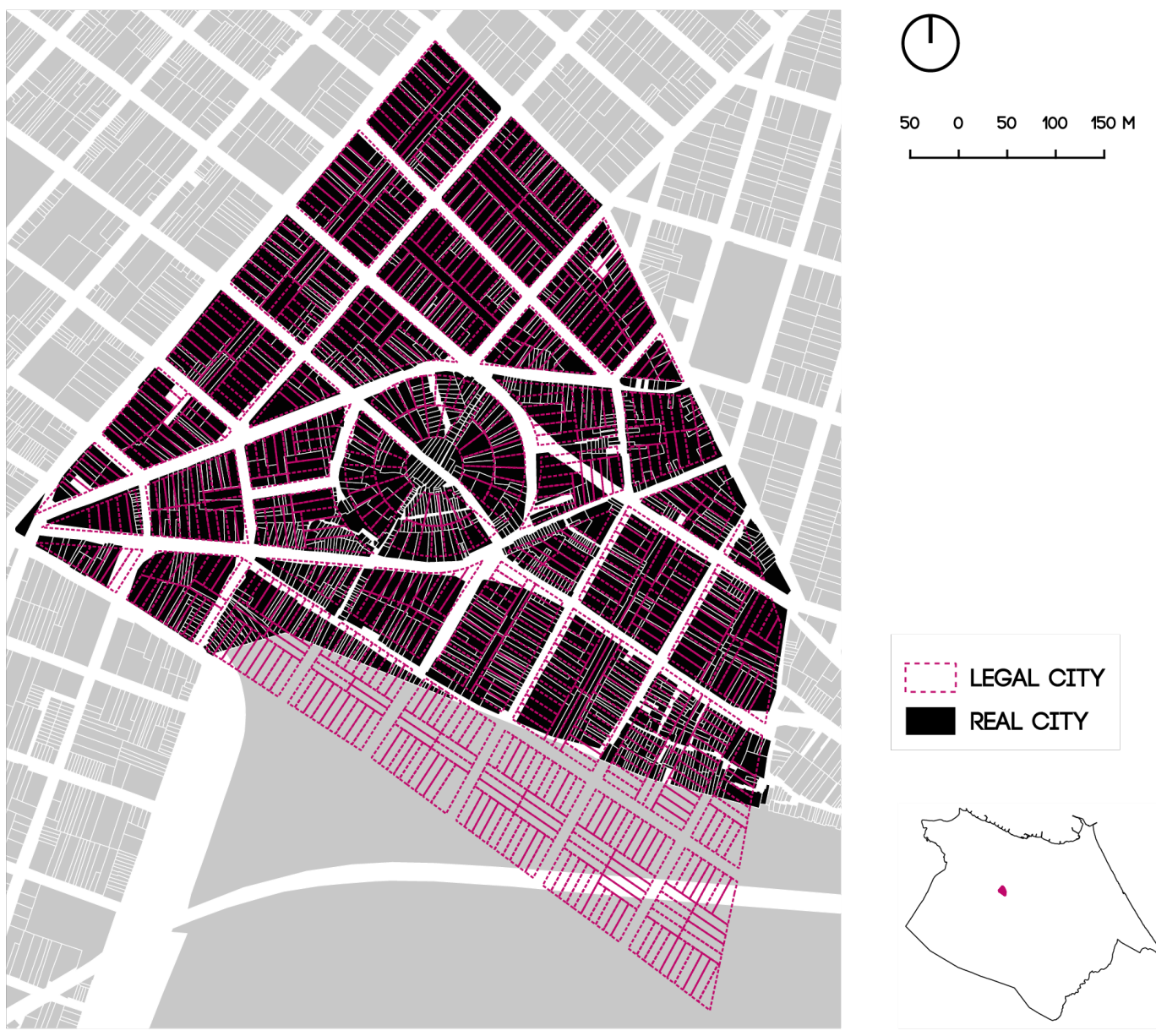

Figure 6. "Parque Coqueirinho" Subdivision (1976).

Source: produced by the authors, based on data from SEUMA, 2015 and SEFIN, 2010.

A major component driving this divergence is the inability of the formal market to adequately respond to a need for affordable land, since, among other things, most of the population is not able to pay the price of the minimum lot size (FREITAS; PEQUENO, 2015). It is noteworthy that, as stated by Smolka (2003), often in Latin American cities the square meter of an informal lot is more expensive than the square meter of a formal one, but a lot with a smaller size (often irregular) end up having a lower total price in comparison with the formal one. That is why it is important to discuss the real outcomes of urban legal parameters, such as minimum lot size, that disregards the reality of most of the population. Smaller lots seem to be, therefore, one of the key conditions for the economic viability of low-income population in serviced portions of the city.

\section{SIMULATING CURRENT URBAN CODING IN THE EXISTING CITY}

In the first exercise of comparison between the legal city and the existing city, we discussed the minimum dimensions of the lot, one of the parameters required in what we will call the first moment of urban licensing: the parceling. The second moment of the urban licensing, which regulates the edification, is based on the regulation that deals with the permitted uses and how the building must occupy the lot (setbacks, coverage, use intensity, height), and the one that deals with the construction of the building (materials, size of the rooms, door and window frame sizes, etc.). Noncompliance to the rules set in these different moments/scales of the 
urban licensing adds more layers to the informality. We will discuss these relationships in this section.

Figure 7. "Parque Vila Velha" modeling.

Source: produced by the authors, based on data from SEUMA, 2015 and SEFIN,

2010.
APPROVED LOTS + BUILDING STANDARDS

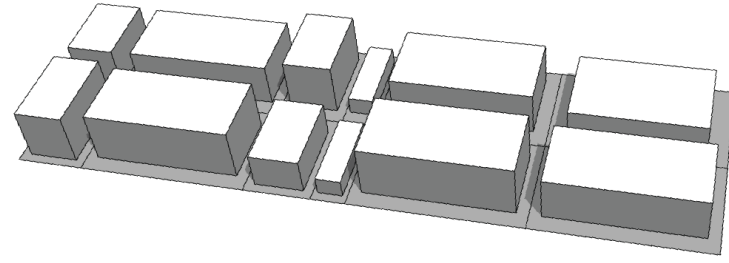

EXISTING LOTS + BUILDING STANDARDS

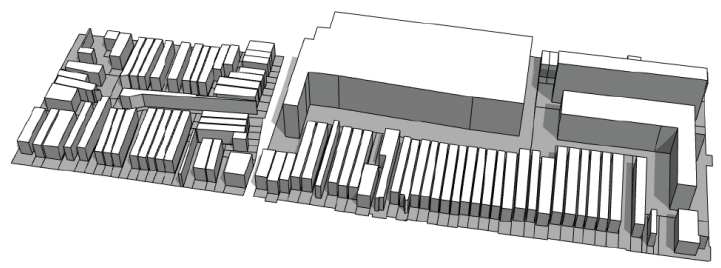

EXISTING SITUATION

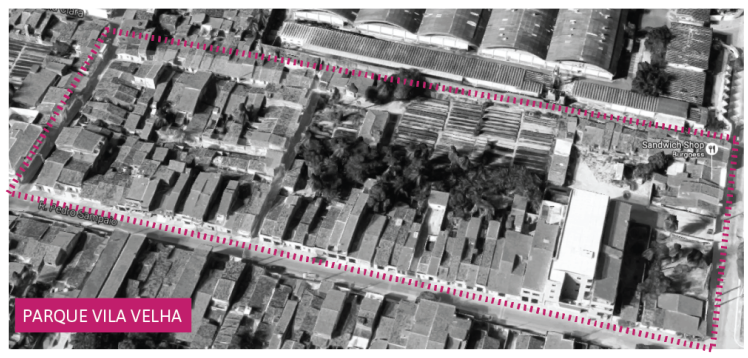

To carry out this analysis we used Esri City Engine, a three-dimensional modeling software specialized in generating model urban environments from a set of predefined rules. One block of each of the subdivisions discussed above was picked to compare three scenarios: the building standards applied to the approved subdivision; the building standards if they were applied to the existing lots; and finally, the view of the actual lot's occupation (Figures 7 and 8). We adopted the building standards that tend to be disregarded for economic survival reasons: the coverage - which is maximum $60 \%$ - and the minimum setbacks - which vary according to the land use, the front size of the lot and the height of the building. These conditions were applied to the respective lots in each scenario.

As we can see in the images, the existing situation is very distant from the planned block. Moreover, if we consider that one would obey the building standards (second moment of urban licensing) even though the lot is undersized (first moment of urban licensing), it becomes often impracticable. This occurs for many reasons, but we argue that one of the reasons is the unrealistic regulation: besides the payment capacity of the population regarding the lot size, often the actual lots are not compatible with the building standards. By trying to produce a landscape that is disconnected with the cultural social and economic reality of major part of 
the residents, urban regulations ended up producing serious morphological problems, such as insufficient open spaces and difficulty of access.

APPROVED LOTS + BUILDING STANDARDS

APPROVED LOTS + BUILDING STANDARDS

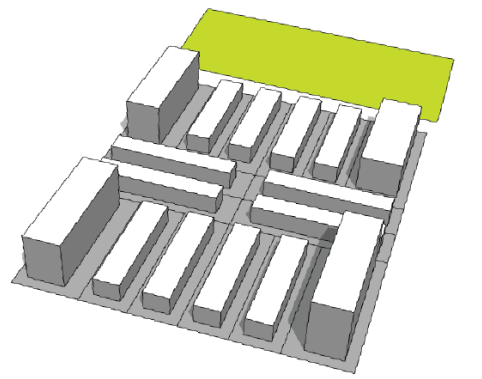

EXISTING LOTS + BUILDING STANDARD

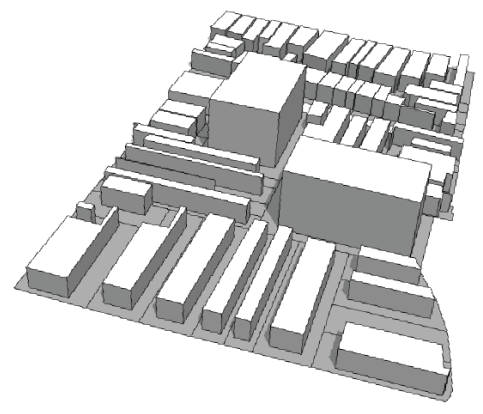

EXISTING SITUATION

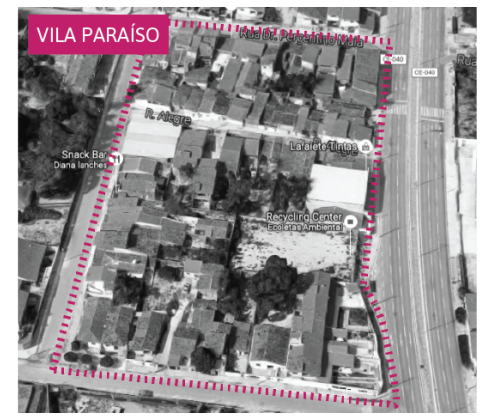

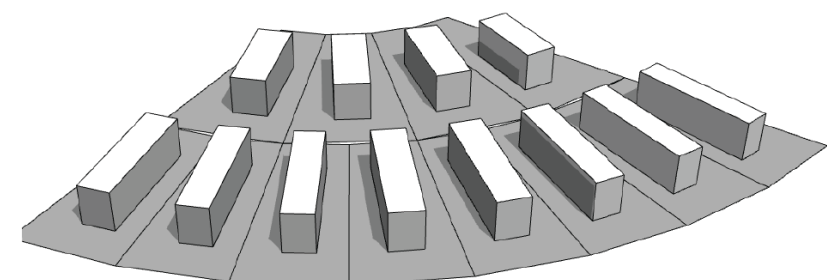

EXISTING LOTS + BUILDING STANDARDS

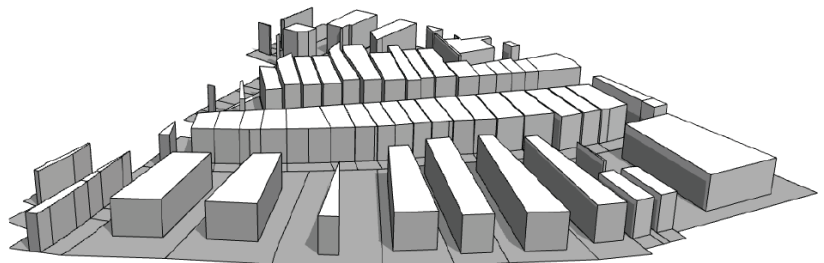

EXISTING SITUATION

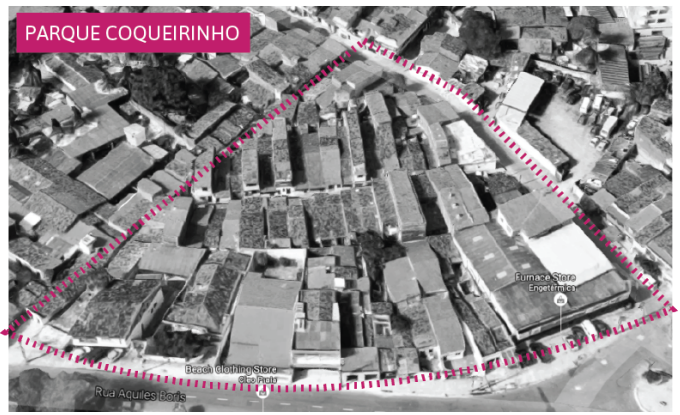

Figure 8. "Vila Paraíso" modeling (Left) and "Parque Coqueirinho" modeling (Right).

Source: produced by the authors, based on data from SEUMA, 2015 and SEFIN, 2010.

City Engine was of great utility to enable fast 3D modeling of the existing situation using data obtained in advance. It works, nevertheless, with shapefiles and not with a database that could be updated. Therefore, despite the ease of use in modeling, the impossibility of working with data at different scales (lots and buildings, for example) severely limits the production of reports, which could be one of its main use cases since it would allow for a more efficient way of describing the existing situation. We could calculate absolute values such as building projection area, building constructed area, and lot area. It was not possible to calculate indicators that depended on the relationship between different scales, such as coverage and building intensity. The descriptive approach, therefore, did not seem to use all the potential that the tool offers, and we can obtain the same or better information from the existing situation with much simpler software such as QGIS (COSTA LIMA; FREITAS; CARDOSO, 2019). 
Regarding the simulation approach, the software allowed to simulate the occupation in a large set of geometries through pre-defined urban parameters and random application. However, it was observed that City Engine lends itself much more to modeling fantasy cities based on randomness - compatible with its initial purpose - than to modeling scenarios based on normative parameters. Therefore, the software treats modeling as an end, and not as a means to analyze either the existing reality or the proposed reality. The fact that the software does not have an active virtual community makes it difficult to exchange knowledge between users of the platform.

Despite these limitations, the results of the methods applied support the previous politicaleconomic analysis, suggesting that, in the case of Fortaleza, invisibility plays an important role in explaining the persistence of informal modes of development. In this sense, the importance of a reality-based regulation is reinforced, which can be fostered by a greater knowledge of the urban form of the existing city, which will be addressed in the next section, using another method as City Engine proved inadequate for this purpose.

\section{A POSSIBLE PATH: DATA-BASED REGULATION}

The current Comprehensive Plan of Fortaleza, enacted in 2009 in order to meet "Statute of the City" (BRASIL, 2001) guidelines, adopts a progressive language in relation to the legitimacy of precarious informal settlements. Yet, its parameters and codes fall short in meeting their spatial requirement. The urban regulations and standards defined by this current plan (PDP), still consider only the morphological and typological patterns of dominant groups, attending the requirements of the formal real estate industry that produce only a small portion of the city. Current planning system opens the possibility of defining different standards in order to allow land titling and upgrading programs in existing settlements, through the assignment of Special Zone for Social Housing (ZEIS). In such zones, that currently comprise 3\% of the territory, new urban codes and standards are to be defined in such a way that warrant some minimum living conditions and do not put the entire settlement under the status of illegality.

These zones, therefore, envisage the elaboration of special norms, but, for them to be elaborated in an informed way (differently from what happened historically in the urban planning of Fortaleza), solid knowledge about the local reality is necessary. This knowledge can be obtained by an effective participation of the residents, but also from a coherent mapping of its urban form (so that the residents can give their opinion in possession of quantitative information). Thus, the method was designed to measure the existing urban form of informal settlements, using as study area, a ZEIS from Fortaleza, ZEIS Bom Jardim, in the southwestern periphery of the city (Figure 9). 


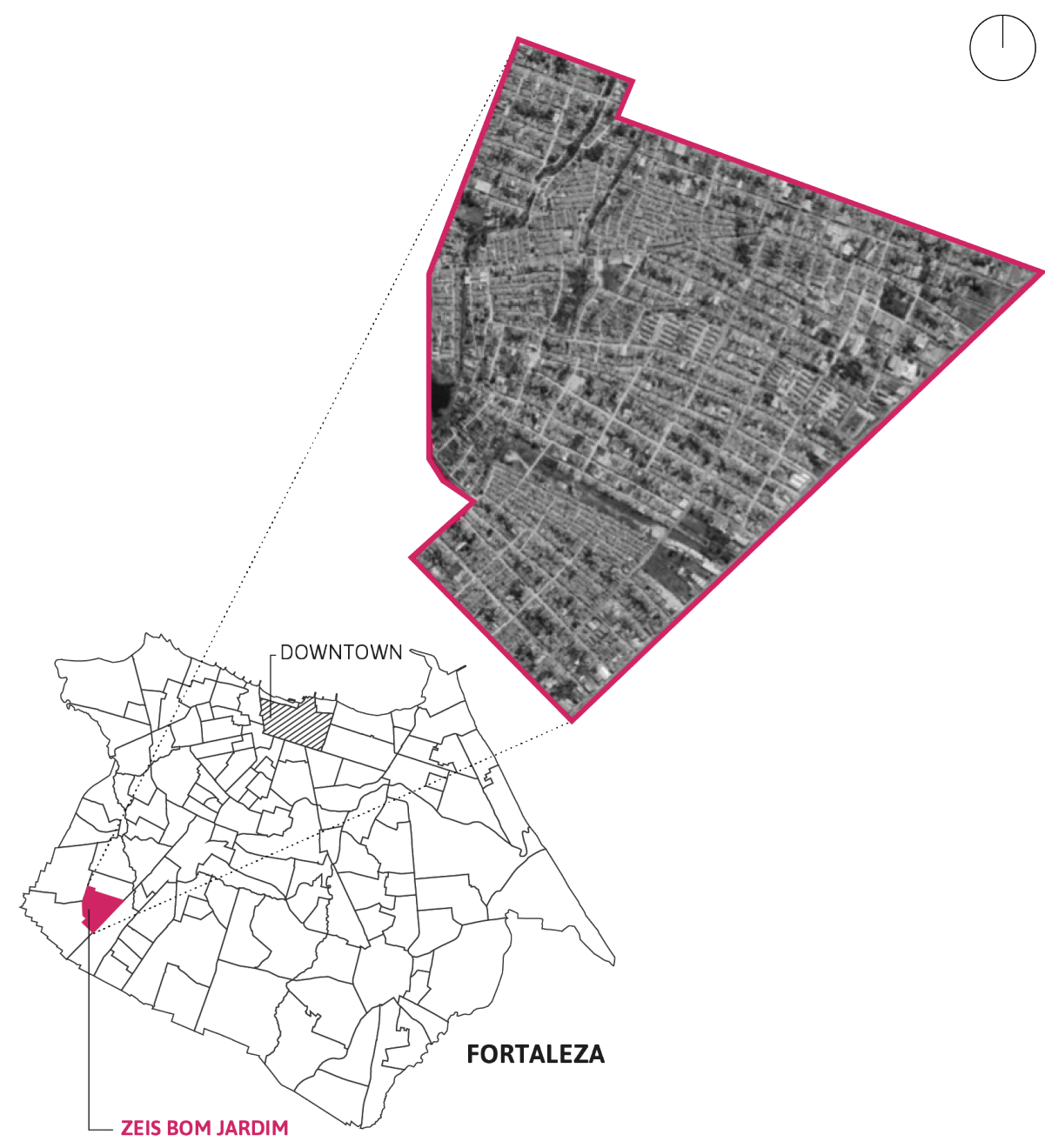

The option for a peripheral ZEIS has important advantages in the application of this case study. In a peripheral region, the threats of eviction or displacement are less common and the urban problems, as results of the lack of investment and protection of the State are evident. On the other hand, the fact that it is a peripheral area also contributes so that the chosen ZEIS has not yet reached a critical level of consolidation before which the preventive nature of regulation seems innocuous. At ZEIS Bom Jardim, it can be seen, even in the most consolidated areas, that a considerable amount of free area per block is still preserved, which can be seen as an opportunity. The choice of ZEIS Bom Jardim, specifically, was given priority due to the partnership, which has been developing since 2013, between the researchers and a very important local NGO.

We measured the urban form of the settlements notably through density indicators, such as those proposed by Berghauser Pont and Haupt (2010), in their work entitled "Space, Density and Urban Form". One of the reasons for using this theoretical apparatus was the correspondence of many of the indicators defined by them with urban planning parameters present in Brazilian legislation, such as Coverage, Building Intensity and Building height. This approach was adapted to the particularities of the informal city of Fortaleza.

The main sources of the geometric data used in the case study were an aerophotogrammetric survey done by the municipality in 2010 and shapefiles produced by the municipal authorities.
Figure 9. ZEIS Bom Jardim's Location in Fortaleza.

Source: produced by the authors. 
It is relevant to note that the lot shapefile designed by the municipality's technical staff is very incomplete. This has to do with the main goal of the agency that produce such spatial data, that is to collect property taxes. As the mapping process is expensive, in the view of the public managers, it is probably not worth it to include the complex geometry of lots located in precarious informal settlements, as low-income residents pay very small amount of property taxes, if at all.

As a result of this "unmapping", only less than 30\% of the whole area in ZEIS Bom Jardim is covered by this official data. Due to the lack of governmental control, spaces destined for green areas and public squares, or institutions had been occupied by the population, which explains the absence of community shared areas. The delimitation of the lots thus demanded, in the case studied, an extensive process of geometry manipulation. This process was necessary since the lot would be the starting point for the measurement of the various density indicators. On the other hand, the buildings shapefile, developed by the city in an automated way based on the aerophotogrammetric survey, is quite complete, including the building height data, in meters.

Our methodology is based on the system developed by Sousa (2018), which, in turn, was based on the system developed by Beirão (2012), called CityMaker. The system we adopted uses QGIS and Grasshopper 3D, an algorithmic modeling tool. Grasshopper is a plug-in available for use in the CAD platform we used (Rhinoceros 3D), where we can visualize the urban form, and which is also connected to PostgreSQL as the object-relational-database management system (ORDBMS). The system can store and manipulate georeferenced spatial data due to the PostGIS expansion which connects QGIS and Grasshopper. In this system, which we detail in previous research (COSTA LIMA; FREITAS; CARDOSO, 2019), we developed some algorithms for the description of the urban form. As part of the broader research agenda, the focus of this paper will be in indicators that are directly related to the forms of occupation of private area, such as lot size, occupation rate and building height.

For this purpose, the algorithm relates each building to its respective lot through the location of their centroids. It is then possible to calculate the occupied area in each lot, the maximum height in each lot and the constructed area. With the results of the occupied area and constructed area, it is possible to calculate - by dividing the results by the respective areas of the lots - the building coverage (GSI) and the building intensity (FSI), respectively.

According to the evaluation of the results (Figure 10), more than $60 \%$ of lots have a total area below the legal minimum of 125 square meters (not considering social housing zones). The smaller size generates problems in terms of occupancy rates: among lots with less than 125 square meters, $80 \%$ have an occupancy rate of above $60 \%$ - the legal maximum allowed by the Comprehensive Urban Plan (Table 1). Beyond affordability issues regarding the lot's size, existing housing is usually non-conforming to other urban legal parameters. Therefore, due to the small size, it is unfeasible to build houses with minimum living areas that meet legal requirements such as occupancy rate, what seems to be a decisive point for the lot's environmental quality. This finding can be observed once the number of lots with occupancy rates higher than allowed (bordering alarming 100\% in some cases) is compared to lots with total area above or below 125 square meters. 


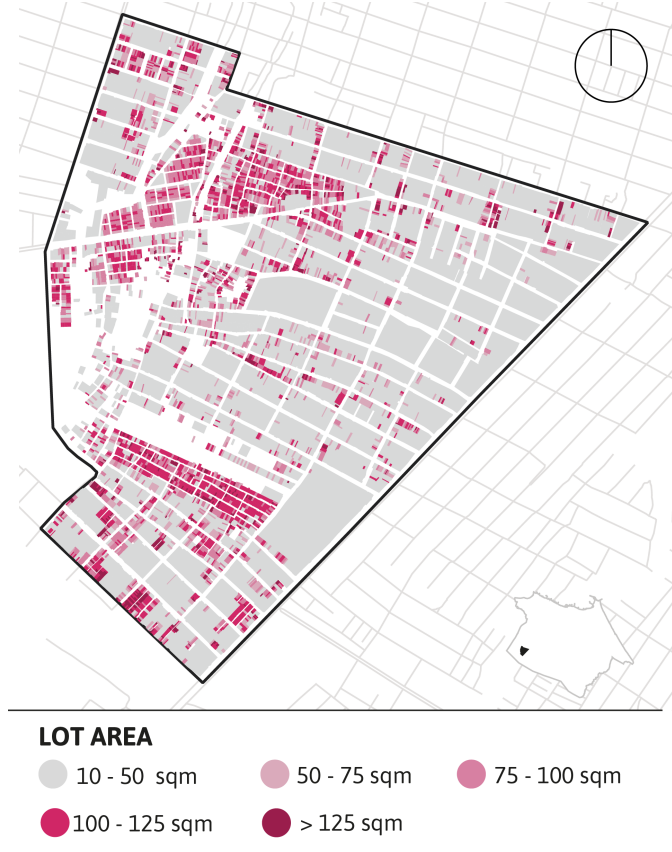

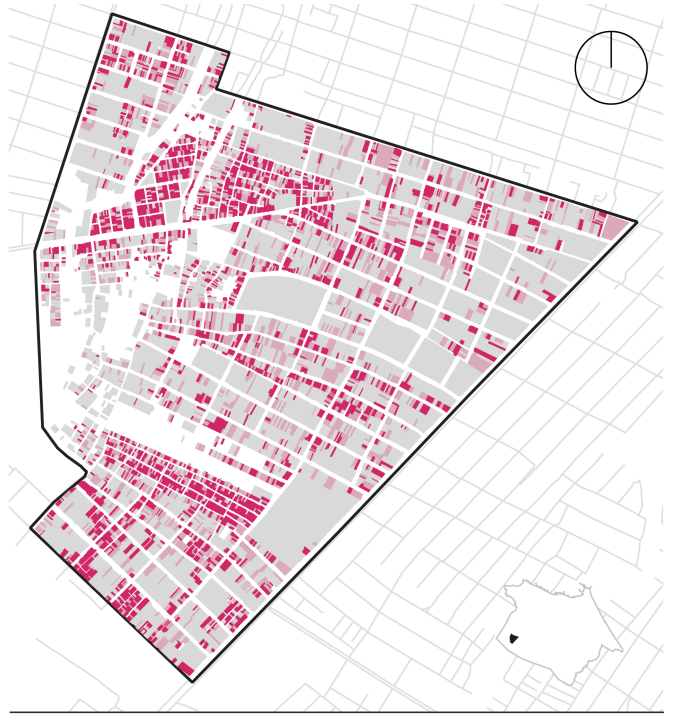

BUILDING COVERAGE

$0-60 \%$ - $60-80 \%$
Figure 10. Lot area (left) and Building coverage (right) in ZEIS Bom Jardim.

Source: produced by the authors based on data from SEFIN, 2010.

\begin{tabular}{l|l|l|l} 
& COVERAGE $<60 \%$ & COVERAGE $>60 \%$ & TOTAL \\
\hline $\begin{array}{l}\text { LOT AREA } \\
\text { 125m2 }\end{array}$ & 1852 & 1004 & 2856 \\
\hline $\begin{array}{l}\text { LOT AREA } \\
\text { 125m2 }\end{array}$ & 926 & 3750 & $\mathbf{4 6 7 6}$ \\
\hline TOTAL & $\mathbf{2 7 7 8}$ & $\mathbf{4 7 5 4}$ & $\mathbf{7 5 3 2}$
\end{tabular}

The combination of GIS and CIM, expanding the sense of information modeling applied to the city studies, allowed the generation of a wide range of urban information from simple geometric data, making it possible to analyze informal settlements not as amorphous and opaque points, but as an urban form, which can be an important contribution for a realitybased regulation.

\section{CONCLUSIONS}

In this work, we sought to counterpose the legal city and the existing city to discuss the role of the invisible informality to legitimize State's arbitrary decisions in regard to urban development.

Historically, informality has been ignored in the representation of 'official city', absent on maps, registers and statistics. By equating informality with illegality - and by treating the informal dwellers as unworthy of rights - the deliberate decision to deny or undercount the phenomenon is justified before society. The case of Fortaleza supports this assertion.

Since the 2000s, we used to talk about "recent advances" in terms of access to information, especially regarding informal settlements, with emphasis on the national census. However,
Figure 10. Quantitative of lots above and below legal thresholds for area and coverage.

Source: produced by the authors. 
more recently, the various budget cuts made by the federal government point to the impossibility of carrying out the new national census, which was previously planned for 2020 (FEITOSA, 2020). This demonstrates how information has power and bestows power, precisely because the lack of information can hide inequalities and privileges.

Different urban stakeholders must be aware of the dynamics present in building and rebuilding a city, as well as the legal mechanism in force to influence those processes. In order to change the logic behind the production and reproduction of urban inequalities, it is imperative to change existing imbalances in the knowledge about different parts of the city. Only then would it be possible to consider effective participation: access to information to all stakeholders is a key requirement for the democratic process. Producing and spreading information on an urban peripheral area in Brazil points to a dialectic process: on the one hand, the technical aspect should be understood as also political; on the other, it is imperative that the political aspect of urbanization be informed by technical data.

The results of the proposed methods reveal that regulation that aims to increase the quality of the built environment in informal settlements requires, first of all, a good understanding of the local reality - an objective for which the representation of this reality is fundamental. By reducing the cost of time and resources to produce geographic information about precarious spaces, new technologies, such as the ones used in this research, open new possibilities of action for urban planners engaged in the implementation of effectively transforming urban policies. Instead of replacing the need to go to the field, new technologies facilitate dialogue with residents, as they allow greater appropriation/familiarity with the studied territory. They become, therefore, an appropriate instrument to start the process of familiarizing the actors involved (representatives of the state, researchers, residents) with the urban context that is intended to qualify, and in particular with the existing morphological patterns. They also produce accurate data on the problems to be addressed, such as the measurement of the tendency towards precariousness in the territory.

The above-described methods are an early version of a system that has been developed and improved by a research group (Laboratório de Experiências Digitais - LED UFC) - in which the authors of this article participate - that has been undertaking several academic studies regarding the manipulation and production of morphological data about the city. Seeking to apply this expertise, local planning agency commissioned the research team to develop a proposal of special regulation and urban plan for 3 informally developed areas in the city of Fortaleza, including ZEIS Bom Jardim, which demonstrates the practical applicability of the proposed methodology. This process has been described in more detail by Costa Lima et al (2020).

While acknowledging that defining, measuring and quantifying the phenomenon is far from sufficient to solve it, we claim that they comprise essential steps toward reconnecting the planning process with the real urban dynamics. Although the awareness of the contribution of these relatively new geotechnologies to urban planning is spreading, the reflection about its use in order to render visible the informal city and to enable more inclusive decisions has hardly begun. Though political challenges may seem unsurmountable and have to be discussed, it is imperative to produce accurate and quality data on urban territorial disputes. Technical hurdles for regulation and regularization of informal settlements might, to a great extent, be overcome with new media, such as geotechnologies, and more specifically CIM, which reveal, in particular, the need to better know and see the current situation in these informal settlements. Technical matters should be discussed and put into question, not only to inform a possible favorable political context, but also to create it. 


\section{References}

BEIRÃO, J. N. CltyMaker: Designing Grammars for Urban Design. [s.I.] TUDelft, 2012.

BERGHAUSER PONT, M.; HAUPT, P. Spacematrix. Rotterdam: NAi Publishers, 2010.

BRASIL. Constituição (1988). Available in:

<http://www.planalto.gov.br/ccivil_03/constituicao/constituicao.htm>. Access in: March 25 mar. 2021.

BRASIL. Lei No 10.257, de 10 de julho de 2001. Regulamenta os arts. 182 e 183 da Constituição Federal, estabelece diretrizes gerais da política urbana e dá outras providências. Diário Oficial [da] República Federativa do Brasil, Brasília, DF, 10 jul. 2001. Available in:

<http://www.planalto.gov.br/ccivil_03/leis/LEIS_2001/L10257.htm>. Access in: March 28th 2021.

CASTELLS, M.; PORTES, A. World underneath: The origins, dynamics, and effects of the informal economy. In: BENTON, L. A. (Ed.). The Informal economy: studies in advanced and less developed countries. Baltimore, Md: Johns Hopkins University Press, 1989.

COSTA LIMA, M. Q.; FREITAS, C. F. S.; CARDOSO, D. R. Modelagem da informação para a regulação urbanística dos assentamentos precários em Fortaleza. urbe. Revista Brasileira de Gestão Urbana, v. 11, e20180199, 2019. DOI: 10.1590/2175-3369.011.e20180199

COSTA LIMA, M. Q.; MOREIRA, E.; FARIAS, S.; FREITAS, C. F. S. A data-driven approach to inform planning process in informal settlements. In: International Conference of the Iberoamerican Society of Digital Graphics, 24., 2020. Proceedings... Medellin: Blucher Design, 2020. DOI: 10.5151/sigradi2020-71.

DUARTE, J. P. et al. City Induction: a model for formulating, generating, and evaluating urban designs. In: ARISONA, S. M. et al. (Eds.). Digital urban modeling and simulation. Communications in computer and information science. Heidelberg: Springer, 2012. p. 73-98.

FEITOSA, F. DA F. Big data e urban analytics à brasileira: questões inerentes a um país profundamente desigual. Revista de Morfologia Urbana, v. 8, n. 1, p. e00141-e00141, 30 jun. 2020. DOI: 10.47235/rmu.v8i1.141

FERNANDES, E. Regularização de Assentamentos Informais na América Latina. [s.l: s.n.].

FORTALEZA. Decreto n. 70, de 13 de dezembro de 1932. Põe em execução o Código de Posturas do Município de Fortaleza. Digitized archive from microfilm copies of newspapers in the Public Archives of the State of Ceará. Available in: http://acervo.fortaleza.ce.gov.br/. Access in: February 8th, 2021.

FORTALEZA. Lei n. 188, de 16 de maio de 1950. Dispõe sobre o Código Urbano do Município de Fortaleza. Available in: http://acervo.fortaleza.ce.gov.br/. Access in: February 8th, 2021.

FORTALEZA. Lei n. 2004, de 06 de agosto de 1962. Dispõe sobre o Código Urbano do Município de Fortaleza. Diário Oficial do Município de Fortaleza, ano I, n. 107, 29 nov. 1952. Available in:

http://acervo.fortaleza.ce.gov.br/. Access in: February 8th, 2021.

FORTALEZA. Lei n. 2128, de 20 de março de 1963. Aprova o Plano Diretor da Cidade de Fortaleza e dá outras providências. Diário Oficial do Município de Fortaleza, ano IX, n. 2741, 23 mar. 1963. Available in: https://sapl.fortaleza.ce.leg.br/media/sapl/public/normajuridica/1963/10809/le21281963.pdf. Access in: February 9th, 2021.

FORTALEZA. Lei n. 5122-A, de 13 de março de 1979. Dispõe sobre o parcelamento, uso e ocupação do solo urbano e dá outras providências. Diário Oficial do Município de Fortaleza, ano XXVI, n. 6639, 24 abr. 1979. Available in: https://sapl.fortaleza.ce.leg.br/media/sapl/public/normajuridica/1979/5832/5122-a.pdf. Access in: February 9th, 2021.

FORTALEZA. Lei n. 5.530, de 17 de dezembro de 1981. Dispõe sobre o Código de Obras e Posturas do município de fortaleza e da outras providências. Diário Oficial do Município de Fortaleza, ano XXIX, n. 7299, 18 dez. 1981. Available in:

https://sapl.fortaleza.ce.leg.br/media/sapl/public/normajuridica/1981/1844/1844_texto_integral.pdf. Access in: February 8th, 2021. 
FORTALEZA. Lei n. 7061, de 16 de janeiro de 1992. Aprova o Plano Diretor de Desenvolvimento Urbano de Fortaleza - PDDU-For e dá outras providencias. Diário Oficial do Município de Fortaleza, ano XXXIX, n. 9788, 20 jan. 1992. Available in:

https://sapl.fortaleza.ce.leg.br/media/sapl/public/normajuridica/1992/780/780_texto_integral.pdf. Access in: February 9th, 2021.

FORTALEZA. Lei Complementar n. 062, de 2 de fevereiro de 2009. Institui o Plano Diretor Participativo do Município de Fortaleza e dá outras providências. Fortaleza: Diário Oficial do Município de Fortaleza, ano LVI, n. 14.020, 13 mar. 2009. Available in:

https://sapl.fortaleza.ce.leg.br/media/sapl/public/normajuridica/2009/107/107_texto_integral.pdf. Access in: February 9th, 2021

FORTALEZA. Prefeitura Municipal. Fundação de Desenvolvimento Habitacional. Plano Local de Habitação de Interesse Social de Fortaleza. Fortaleza, 2012

FREITAS, C. F. S. Ilegalidade e degradação em Fortaleza: os riscos do conflito entre a agenda urbana e ambiental brasileira. urbe. Revista Brasileira de Gestão Urbana, v. 6, n. 1, p. 109-125, 2014. DOI:

10.7213/urbe.06.001.AC02

FREITAS, C. F. S.; GOMES, V.; BORGES, M. Planejamento Urbano com uso de Sistemas de Informação Geográfica: O caso de Feira de Santana, BA. Universitas: Arquitetura e Comunicação Social, v. 10, n. 1, p. 10, 2013. DOI: http://dx.doi.org/10.5102/uc.v10i1.1947

FREITAS, C. S.; PEQUENO, L. R. B. Produção Habitacional na Região Metropolitana de Fortaleza na década de 2000: avanços e retrocessos. Revista Brasileira de Estudos Urbanos e Regionais, v. 17, n. 1, p. 45, 25 abr. 2015. DOI: 10.22296/2317-1529.2015v17n1p45

IBGE. Aglomerados Subnormais: Informações territoriais. Censo demográfico 2010. Rio de Janeiro: IBGE INSTITUTO BRASILEIRO DE GEOGRAFIA E ESTATÍSTICA., 2010. Disponível em:

$<$ https://biblioteca.ibge.gov.br/index.php/biblioteca-catalogo?view=detalhes\&id=7552>. Acesso em: 20 mar. 2020.

KANBUR, R. Conceptualising Informality: Regulation and Enforcement: IZA Discussion Paper. Germany: IZA \& Cornell University, 2009. Disponível em: <http://repec.iza.org/dp4186.pdf>. Acesso em: 19 jun. 2021.

LUQUE-AYALA, A.; NEVES MAIA, F. Digital territories: Google maps as a political technique in the re-making of urban informality. Environment and Planning D: Society and Space, v. 37, n. 3, p. 449-467, 2019. DOI: $10.1177 / 0263775818766069$

MARICATO, E. Metrópole na periferia do capitalismo: ilegalidade, desigualdade e violência. São Paulo: Editora Hucitec, 1996.

MARTINS, M. L. R. Globalização, Informalidade e Regulação em cidades latino-americanas. Brazilian Journal of Latin American Studies, v. 5, n. 8, p. 31-50, 1 jun. 2006. DOI: 10.11606/issn.1676-6288.prolam.2006.81798

MUKHIJA, V.; EHRENFEUCHT, R.; LOUKAITOU-SIDERIS, A. (EDS.). The Irreconcilable Tension between Dwelling in Public and the Regulatory State. In: The informal American city: Beyond taco trucks and day labor. Urban and industrial environments. Cambridge, Massachusetts: The MIT Press, 2014. p. 155-172.

MUKHIJA, V.; LOUKAITOU-SIDERIS, A. (EDS.). The informal American city: Beyond taco trucks and day labor. Cambridge, Massachusetts: The MIT Press, 2014.

PEREIRA, G. C.; SILVA, B.-C. N. Geoprocessamento e Urbanismo. In: GERARDI, L. H. DE O.; MENDES, I. A.; UNIVERSIDADE ESTADUAL PAULISTA (Eds.). . Teoria, técnica, espaços e atividades: temas de geografia contemporânea. Rio Claro, SP: Programa de Pós-Graduação em Geografia, UNESP : Associação de Geografia Teorética, 2001. p. 97-137.

ROLNIK, R. A cidade e a lei: legislação, política urbana e territórios na cidade de São Paulo. São Paulo, SP: FAPESP : Studio Nobel, 1997.

ROLNIK, R. Guerra dos lugares: a colonização da terra e da moradia na era das finanças. 1ạ edição ed. São Paulo, SP: Boitempo, 2015. 
ROY, A. Urban Informality: Toward an Epistemology of Planning. Journal of the American Planning Association, v. 71, n. 2, p. 147-158, 30 jun. 2005. DOI: 10.1080/01944360508976689

ROY, A. Why India Cannot Plan Its Cities: Informality, Insurgence and the Idiom of Urbanization. Planning Theory, v. 8, n. 1, p. 76-87, 1 fev. 2009. DOI: 10.1177/1473095208099299

SMOLKA, M. Regularização da Ocupação do Solo Urbano: O problema que é parte da solução, a solução que é parte do problema. In: ABRAMO, P.; TASCHNER, S. P. (Eds.). . A cidade da informalidade: o desafio das cidades latino-americanas. Rio de Janeiro: Livraria Sette Letras : FAPERJ, 2003.

SOUSA, C. E. M. DE. Modelando a percepção: o ambiente do patrimônio cultural edificado na regulação da forma urbana. 2018. Disponível em: http://www.repositorio.ufc.br/handle/riufc/37245.

UN-HABITAT (ED.). Bridging the urban divide. London: Earthscan, 2010.

Mariana Quezado Costa Lima marianaqcl@gmail.com

Clarissa Figueiredo Sampaio Freitas

clarissa@arquitetura.ufc.br

Daniel Ribeiro Cardoso danielcardoso@ufc.br 